\title{
SOME NOTEWORTHY RECORDS OF COWBIRD PARASITISM IN SOUTHERN ALBERTA
}

by Norbert G. Kondla, 4320 Bowness Road, and Harold W. Pinel, 1017 - 19 Avenue N.W., Calgary

The abservations contained herein were made from 1967 to 1971 in southern Alberta. Included are records of parasitism of species which are apparently not frequently parasitized, and some interesting records of species which are frequently parasitized by the Brown-headed Cowbird (Molothrus ater) (Friedmann. Host relations of the parasitic cowbirds. U.S. Natl. Mus. Bull. No. 233. 1963).

Dusky Flycatcher

(Empidonax oberholseri)

Kondla observed a nest of this species containing three flycatcher eggs and one cowbird egg on June 22, 1968 at Norman Lake. The nest was six feet up in the crotch of a large willow (Salix sp.) in a grove of aspen poplar (Populus tremuloides) about 50 feet from Norman Lake. Of six Dusky Flycatcher nests observed in the area, this is the only instance of parasitism. Friedmann (1963) did not list any records of parasitism of this species.

\section{Horned Lark (Enemophila alpestris)}

Pinel discovered a lark nest on June 6, 1970 at Little Bow Lake. The nest was beside dry cattle dung on heavily grazed native grassland and contained three lark eggs and one cowbird egg. There is only one previous record for Alberta as noted by Friedmann (1963).

\section{Swainson's Thrush}

(Hylocichla ustulati)

On June 19, 1968 Kondla found a nest containing four thrush eggs and four cowbird eggs at Norman Lake. One of the thrush eggs had a small puncture in the shell. The nest was three feet up in a willow in a mixed stand of aspen poplar and white spruce (Picea glauca). The next year in the same place the same observer noted a thrush nest four feet up in a small white spruce containing three thrush eggs and three cowbird eggs. Four pre. vious records of parasitism of this species in Alberta have been noted by Friedmann (1963).

\section{Yellow Warbler}

\section{(Dendroica petechia)}

Friedmann says that this is one of the most frequently parasitized species. Our observations are in full support of this. One interesting nest, however, was found by Pinel on June 21, 1970 at Calgary in which a pair of warblers was incubating a single cowbird egg. On June 24 the warblers were still incubating the egg, but on June 28 the nest was empty.

Red-winged Blackbird (Agelaius phoeniceus)

Friedmann (1963) noted that in Maryland the Redwing was almost invariably parasitized in the early clutches and that later, when other hosts became available, cowbirds rarely bothered blackbirds. Pinel observed a late record of parasitism by finding a nest containing four Redwing eggs and one cowbird egg on June 27, 1970 at Traver's Reservoir. The nest, which was one of six, was situated in cattails (Typha latifolia) about 10 feet from shore. Friedmann reported that Roberts is 1932 in Minnesota found that nests of Redwings in marshes were not parasitized, but nests in bushes near marshes were parasitized regularly. Friedmann also quotes Nickell as stating that solitary nests or nests at the periphery of the colony were more parasitized than those nests in the midst of the colony. Nickell attributed this fact to the combined aggressiveness and vigilance of the blackbirds. Except for the observation by Pinel that was mentioned above, our findings are in agreement with Roberts and Nickell. On May 31, 1970 Pinel checked 26 Redwing nests in a marsh 
at the north end of Namaka Lake and found no parasitized nests. On the same day, Kondla and Pinel found 35 nests in a marsh at Langdon, none of which was parasitized.

\section{Brewer's Blackbird}

\section{(Euphagus cyanocephalus)}

Friedmann states that this species is frequently imposed upon by cowbirds in Alberta and Montana. This is in full agreement with our observations as outlined in Tables 1 and 2. All of the nests reported at Calgary were part of a colony nesting in a cemetery on the eastern outskirts of Calgary on Highway 1A. Out of 17 nests in 1970, nine contained cowbird eggs, or, in other words, 53 percent of the Brewer's Blackbird nests were parasitized. In 1971 only six blackbird nests were checked at the same locality, and four of these proved to be parasitized. The four cowbird eggs found in nest 15 (Table I) varied considerably in size and markings indicating that different female cowbirds deposited eggs in the nest. Besides the three blackbird eggs found in nest 17 (Table I), there was also a blackbird egg found on the ground under the nest.

Table 2 summarizes the observations of Kondla at Dinosaur Provincial Park, and differs from the preceding table in that the nests were visited more than once.

The nests at Dinosaur Provincial Park were within an area of two acres and there was no noticeable difference in appearance between the cowbird eggs. On June 18 the cowbird eggs

Table 1. Contents of Brewer's Blackbird nests at Calgary, Alberta in 1970 and 1971.

\begin{tabular}{|c|c|c|c|c|c|}
\hline $\begin{array}{l}\text { Nes } \\
\text { No. }\end{array}$ & Date & $\begin{array}{l}\text { Eggs ir } \\
\text { Blackbird }\end{array}$ & $\begin{array}{l}n \text { nest } \\
\text { Cowbird }\end{array}$ & Nest description & bservers \\
\hline 1 & May 20, 1970 & 4 & 0 & $5 \mathrm{ft}$ up in a blue spruce & H. Pinel \\
\hline 2 & May 20, 1970 & 4 & 0 & $3 \mathrm{ft}$ up in a caragana bush & H. Pinel \\
\hline 3 & May 20,1970 & 1 & 0 & $9 \mathrm{ft}$. up in crotch of blue spruce & H. Pinel \\
\hline 4 & May 20, 1970 & 3 & 1 & $4 \mathrm{ft}$. up in crotch of blue spruce & H. Pinel \\
\hline 5 & May 20,1970 & 1 & 0 & 5 fit. up in blue spruce & H. Pinel \\
\hline 6 & May 20, 1970 & 2 & 1 & $4 \mathrm{ft}$. up in caragana bush & H. Pinel \\
\hline 7 & May 20, 1970 & 2 & 0 & $4 \mathrm{ft}$. up in blue spruce & H. Pinel \\
\hline 8 & May 23, 1970 & 6 & 1 & $5 \mathrm{ft}$. up in crotch of blue spruce & H. Pinel \\
\hline 9 & May 23, 1970 & 5 & 1 & $\begin{array}{l}3 \mathrm{ft} \text { up on horizontal limb } \\
\text { of blue spruce }\end{array}$ & H. Pinel \\
\hline 10 & May 23, 1970 & 4 & 0 & $4 \mathrm{ft}$ up on limb of blue spruce & H. Pinel \\
\hline 11 & May 23, 1970 & 2 & 1 & $3 \mathrm{ft}$. up on limb of blue spruce & ce H. Pinel \\
\hline 12 & May 30,1970 & 5 & 1 & $2 \mathrm{ft}$. up in caragana bush & H. Pinel \\
\hline 13 & May 30,1970 & 3 & 1 & $4 \mathrm{ft}$. up on limb of blue spruce & ce H. Pinel \\
\hline 14 & May 30,1970 & 4 & 0 & $4 \mathrm{ft}$. up in crotch of blue spruce & ce H. Pinel \\
\hline 15 & May 30,1970 & 3 & 4 & $1 \mathrm{ft}$ up in Cotoneaster hedge & H. Pinel \\
\hline 16 & May 30,1970 & 3 & 0 & $3 \mathrm{ft}$. up in caragana bush & H. Pinel \\
\hline 17 & May 30,1970 & 3 & 2 & $3 \mathrm{ft}$. up in blue spruce & H. Pinel \\
\hline 18 & May 23, 1971 & 5 & 1 & $3 \mathrm{ft}$. up in blue spruce & H. Pinel \\
\hline 19 & May 23, 1971 & 5 & 1 & $\begin{array}{l}6 \mathrm{ft} \text {. up in blue } \\
\text { spruce }\end{array}$ & $\begin{array}{l}\text { I. Pinel and } \\
\text { C. Wallis }\end{array}$ \\
\hline 20 & May 23, 1971 & 1 & 0 & $\begin{array}{l}4 \mathrm{ft} \text {. up in caragana } \\
\text { bush }\end{array}$ & $\begin{array}{l}\text { [. Pinel and } \\
\text { C. Wallis }\end{array}$ \\
\hline 21 & May 23, 1971 & 5 & 0 & $\begin{array}{l}3 \mathrm{ft} \text {. up in blue } \\
\text { spruce }\end{array}$ & $\begin{array}{l}\text { I. Pinel and } \\
\text { C. Wallis }\end{array}$ \\
\hline 22 & May 23, 1971 & 5 & 1 & $\begin{array}{l}2 \mathrm{ft} \text {. up in Mugho } \\
\text { pine }\end{array}$ & $\begin{array}{l}\text { Pinel and } \\
\text { C. Wallis }\end{array}$ \\
\hline 23 & May 23, 1971 & 6 & 1 & $\begin{array}{l}4 \text { ft. up in caragana } \\
\text { bush }\end{array}$ & $\begin{array}{l}\text { Pinel and } \\
\text { C. Wallis }\end{array}$ \\
\hline
\end{tabular}


remaining in nests 7 and 8 were cold; a subsequent check showed that incubation appeared to be about one-half complete. The disappearance of egg's and young in some nests could be due to the activities of house cats and bullsnakes (Pituophis melanoleucus).

\section{Savannah Sparrow \\ (Passerculus sandwichensis)}

According to Friedmann (1963), the Savannah Sparrow is a very infrequent victim of the Brown-headed Cowbird and there are only three old records of parasitism for Alberta. A recent incident was noted by Kondla on May 28, 1970 at Eagle Lake. The nest, which was a depression on the ground amongst dense grass, contained three sparrow eggs and one cowbird egg. Two of the sparrow eggs each exhibited several small punctures.

\section{Slate-colored Junco \\ (Junco hyemalis)}

Pinel discovered a nest at Norman Lake on June 18, 1970 containing two junco eggs and one cowbird egg. The nest was on the ground along the margin of a brush pile and soil mound in damp, lush vegetation. The egg's were on the verge of hatching which indicates the possibility of successful parasitism. This species seems to be an infrequent host as Friedmann (1963) lists only 18 instances of parasitism.

Table 2. Contents of Brewer's Blackbird nests at Dinosaur Provincial Park, Alberta.

\begin{tabular}{|c|c|c|c|c|c|c|}
\hline \multirow[b]{3}{*}{ Nest No. } & \multicolumn{5}{|c|}{ Contents of nest } & \multirow[b]{3}{*}{ Description of nest } \\
\hline & \multirow[b]{2}{*}{ Date } & \multicolumn{2}{|c|}{ Blackbird } & \multicolumn{2}{|c|}{ Cowbird } & \\
\hline & & young & eggs & young & eggs & \\
\hline 1 & May 19,1971 & & 1 & & & \multirow{5}{*}{$\begin{array}{l}4 \mathrm{ft} \text {. above ground } \\
\text { in Shepherdia } \\
\text { argentea }\end{array}$} \\
\hline & May 25, 1971 & & 4 & & & \\
\hline & May 31,1971 & & 4 & & & \\
\hline & June 7, 1971 & 3 & 1 & & & \\
\hline & June 18,1971 & 1 & & & & \\
\hline \multirow[t]{4}{*}{2} & May 19,1971 & & 4 & & & \multirow{4}{*}{$\begin{array}{l}5 \mathrm{ft} \text {. above ground } \\
\text { in Shepherdia } \\
\text { argentea }\end{array}$} \\
\hline & May 31,1971 & & 2 & & & \\
\hline & June 7,1971 & 2 & & & & \\
\hline & June 18,1971 & 0 & & & & \\
\hline \multirow[t]{4}{*}{3} & May 18,1971 & & 1 & & & \multirow{4}{*}{$\begin{array}{l}3 \mathrm{ft} \text {. above ground } \\
\text { in Shepherdia } \\
\text { argentea }\end{array}$} \\
\hline & May 19,1971 & & 2 & & & \\
\hline & May 25,1971 & & 2 & & 1 & \\
\hline & May 31,1971 & & 0 & & 0 & \\
\hline \multirow[t]{4}{*}{4} & May 19,1971 & & 4 & & & \multirow{4}{*}{$\begin{array}{l}3 \mathrm{ft} \text {. off ground in } \\
\text { chokecherry bush }\end{array}$} \\
\hline & May 31,1971 & & 2 & & 2 & \\
\hline & June 7,1971 & & 2 & & 2 & \\
\hline & June 18,1971 & 2 ur & identi & d young & & \\
\hline \multirow[t]{2}{*}{5} & May 20, 1971 & & 5 & & & \multirow{5}{*}{$\begin{array}{l}4 \mathrm{ft} \text {. off ground in } \\
\text { chokecherry bush } \\
3 \mathrm{ft} \text {. above ground } \\
\text { in Shepherdia } \\
\text { argentea }\end{array}$} \\
\hline & May 31,1971 & & 0 & & & \\
\hline \multirow[t]{3}{*}{6} & May 31,1971 & & 4 & & & \\
\hline & June 7,1971 & 3 & 1 & & & \\
\hline & June 18,1971 & 1 & & & & \\
\hline \multirow[t]{2}{*}{7} & June 7,1971 & 4 & 1 & & 1 & $2 \mathrm{ft}$. above ground \\
\hline & June 18, 1971 & 0 & 0 & & 1 & in Artemisia cana \\
\hline \multirow[t]{3}{*}{8} & May 31,1971 & & 3 & & 2 & $2 \mathrm{ft}$. above ground \\
\hline & June 7,1971 & 3 & & 1 & 1 & in Shepherdia \\
\hline & June 18,1971 & 0 & & 0 & 1 & argentea \\
\hline \multirow[t]{3}{*}{9} & June 7, 1971 & 4 & & & & $5 \frac{1}{2} \mathrm{ft}$. above ground \\
\hline & June 18,1971 & 3 & & & & in Shepherdia \\
\hline & & & & & & argentea \\
\hline
\end{tabular}


Chipping Sparrow

(Spizella passerina)

Although the Chipping Sparrow is a common victim, Friedmann (1963) stated that he knew of no records of nest desertion due to the presence of cowbird eggs. On May 29, 1969 we discovered a nest of this species containing one sparrow egg and one cowbird egg. A visit to the same nest on June 5 revealed only the cowbird egg in the nest and it was cold. Kondla found three cowbird eggs in a Chipping Sparrow nest which contained no sparrow eggs at Norman Lake on June 19, 1968. The nest was one foot up in a white spruce sapling. The eggs were cold when found.
Chestnut-collared Longspur

(Calcarius ornatus)

Friedmann (1963) states that observations of parasitism in nests of this species have been reported regularly only from North Dakota, and that most of these were in the 1890 's. One of the most recent observations is again from North Dakota on June 19, 1933 by George C. Whithey. Kondla found a Chestnut-collared Longspur nest on May 27, 1967 at Lake Newell which contained two longspur eggs and two cowbird eggs. This appears to be one of the most recent observations and the first record from Alberta.

\section{SOME BREEDING ASPECTS OF HERRING GULLS AT KAWINAW LAKE, MANITOBA}

by Kees Vermeer, Canadian Wildlife Service, Edmonton

Incidental to a study of egg laying chronology and food habits of Herring Gulls (Larus argentatus) during May and June, 1971 on two small islands in Kawinaw Lake, $52^{\circ} 50^{\prime} \mathrm{N}$; $99^{\circ} 29^{\prime} \mathrm{W}$, Manitoba, data were collected on egg size, egg laying intervals, incubation periods, clutch size and hatching success. Little is known about these subjects for inland populations of this species in North America.

Egg measurements were taken of the first (I egg), second (II egg) and third eggs (III egg) laid in 39 clutches and are compared with those of Herring Gull eggs measured in Europe
(Table 1). The third egg was on the average smaller than the first two eggs laid, a common phenomenon in gulls (Vermeer, 1969). Egg dimensions at Kawinaw Lake appear similar to those in Denmark and Norway, but dissimilar to those in England. According to Barth (1967), who extensively measured body parts of Herring Gulls in northern Europe, the British population is a separate form of that in Fen. noscandia. No body measurements of Herring Gulls were made at Kawinaw Lake.

Egg laying intervals and incubation reriods were determined for clutches

Table 1. Mean length and width of eggs I, II and III in $\mathrm{mm}$ in Herring Gulls.

\begin{tabular}{|c|c|c|c|c|c|c|c|c|}
\hline \multirow{2}{*}{ Authority } & \multirow{2}{*}{ Location } & \multirow{2}{*}{$\begin{array}{c}\text { No. of } \\
\text { clutches } \\
\text { measured }\end{array}$} & \multicolumn{3}{|c|}{$\begin{array}{l}\text { Mean length of eggs } \\
\text { in } \mathrm{mm}\end{array}$} & \multicolumn{3}{|c|}{ Mean width of eggs } \\
\hline & & & I & II & III & $\mathrm{I}$ & II & III \\
\hline Harris, 1964 & England & 100 & 68.7 & 68.7 & 66.5 & 48.3 & 48.4 & 46.3 \\
\hline Paludan, 1951 & Denmark & 57 & 72.4 & 72.1 & 69.2 & 50.6 & 50.5 & 49.2 \\
\hline Barth, 1967 & North Norway & 59 & 73.7 & 73.5 & 71.4 & 50.6 & 50.7 & 49.5 \\
\hline Barth, 1967 & Middle Norway & 76 & 72.8 & 72.3 & 70.2 & 49.4 & 49.7 & 48.3 \\
\hline Barth, 1967 & South Norway & 18 & 73.2 & 72.2 & 71.2 & 50.2 & 50.5 & 49.5 \\
\hline This study, 1971 & Canada & $39^{*}$ & 72.7 & 73.7 & 71.9 & 50.1 & 50.5 & 49.3 \\
\hline
\end{tabular}

* Standard errors for the mean length and width of the I, II and III eggs were $0.6,0.3,0.5,0.3,0.7$ and 0.4 respectively. 